\title{
Morphological analysis of the Woji River in Port Harcourt, Nigeria; using temporal data and mathematical algorithm
}

\author{
Michael U. K. Anya, Clinton I. Ezekwe, Charles U. Oyegun \\ Department of Geography and Environmental Management, University of Port Harcourt, Nigeria; Clinton.ezekwe@uniport.edu.ng
}

\begin{abstract}
The research analysed morphological variations of the Woji River between 1986 and 2016 using mathematical extrapolations and temporal data. A 50\% reduction in the River mean channel width, fullbank discharge and the stream power was found. Channel siltation occurred due to high sediment fluxes from rapid urban processes versus reduced stream power of the river. Water hyacinth invasion, domestic waste dumps and narrow culvers constricted the river channels. Finally, an impaired river status was found and extinction projected by 2043. Recommended were correction and monitoring exercises to check activities along the river channel and to restore the head stream wetlands.
\end{abstract}

Keywords: channel morphology, river catchment, rivers state, urbanization, mathematical algorithm, Nigeria

\section{Introduction}

The morphology of a river describes the geomorphic parameters of its channel/gully and by its implication explains how the river profile has changed in shape and direction over time. A given river channel dynamics can result out of a number of processes amidst the pressing environmental conditions: such as the geologic composition of the region, the river bed and banks rock structures, vegetation availability, volume and rate of Horton's Overland Flows, the available upland loose sediments, in-channel sediment sizes and composition, net sediment transportation within the channel and the consequent depositions on the river floodplain, bed and bank, and the general basin net denudation events (Zhu et al. 2017). Apart from these natural factors as mentioned, most urban situated rivers, such as the Woji River, are predominantly haunted by anthropogenic causes (Oyegun 1997, Booth 1991). Human interaction with the river governing hydraulic variables ends up in interfering with its natural state of dynamic equilibrium, yielding environmentally unpalatable responses of channel adjustments, bank erosion or silting-up of gully and consequent flooding, most times, completely changing its morphological attributes (Paul, Meyer 2001, Chin 2006, Adebayo, Arohunsoro 2014).

The Woji River, in this instance, is situated right at the heart of Port Harcourt cosmopolitan city within the Nigeria Niger Delta region, where it is currently experiencing serious alterations in its fluvial discharges and its channel morphometry consequent the rapid urbanization of its basin (Weli, Ideki 2014). This has resulted in its observed shrinking flow channels coupled with persisting flooding experiences over its banks thereby endangering the resident communities (Chin 2006). Repetitive flooding of houses and other economic properties especially, those within the river floodplains, is now at a disastrous level; a recurring and persistent event on the dailies and news. Though arguably, the river might not hold much economic value when considered for potable uses, however the risk of losing its other ecosystem services of biodiversity hosting, biogeochemical and hydro-climatic cycles' support and natural purification service of its headstream wetlands is very high. These all must be preserved to yield a sustainable home for man in nature.

The human environment and all the associated physical variables function interdependently on one another such that there is no vacuum in human-na- 
ture interplay. Thus, this geomorphological study of the Woji River drainage basin, therefore, adopts a systemic approach as an explanatory paradigm of its interactions and the resulting form(s) and event(s). The early descriptive approach of patterns and trends of phenomena in space (Ofomata 2009), though remains fundamental, was not applied in this study. Rather, the study adopts the processes and system geomorphology approach.

Most urban planning and development activities, especially in third world countries, as it is with this study area, do not take the fundamental aspects of geomorphic interrelationships in nature into consideration; therefore leaving cities at the mercy of natural hazards like floods and erosions emanating from the systemic response to such unplanned alterations of its composite variables (UNDP 2004). This is one of such incidences found to have occurred within the Woji River basin, inspiring the geomorphometric analysis of the operations within, especially the mode in which the urban land use activities have impacted on the cross section morphology of the main stream (Boix-Fayos et al. 2007). This study therefore looked at the current and future effects of human interference on the channel morphology of the Woji River from a spatio-temporal and mathematical approach.

\section{Study Area}

\section{Location and Extent}

The Woji River drainage basin is situated at the heart of Obio-Akpor Local Government Area in Port Harcourt metropolis, Rivers State, Nigeria. The region falls within latitudes $4^{\circ} 50^{\prime} 25^{\prime \prime} \mathrm{N}$ and $4^{\circ} 48^{\prime} 16^{\prime \prime} \mathrm{N}$ and longitudes $7^{\circ} 03^{\prime} 34^{\prime \prime} \mathrm{E}$ and $7^{\circ} 04^{\prime} 22^{\prime \prime} \mathrm{E}$ using the WGS84 (Fig. 1). Of the 22 Local Government Areas making up Rivers State, Obio-Akpor lies at the centrality of Port Harcourt Township, and covers a land area of $260 \mathrm{~km}^{2}$ with a human population of 878,890 (NPopC 2010). The demography of Obio-Akpor Local Government Area helps to reflect how densely populated Woji area is, as one of the well urbanized regions of the Obio-Akpor kingdom. The Woji River drainage basin also hosts the major industrial hubs of the Port Harcourt city, namely the Trans-amadi Industrial Layout to its South, the Shell Industrial layout to its West, and the Eleme Petrochemical and Fertilizer complex to the South-east of the basin. While its northern axis is fully preoccupied with densely populated housing scheme emanating from the labour and commerce demands of these industrial sites around it.



Fig. 1. Location of the Woji River drainage basin 
The network order of the Woji region is that of third order basin, drained by the Woji River and its tributaries. Two wetland regions, one at the Rumuodara forest to the east of the river head and the other at the Rukpokwu forest to its west, hold the river source and its main recharge points. These head streams flow in separate channels through the swamps of Rumuodumaya and Rumuodara converging at Eliozu, where they form a well-defined river channel. The river journeys from this point through the 'Airforce land' adjacent to the ARIK Air aerodrome and meandered through the Cocaine Estate to manifest at Aba-Port Harcourt Express way. It continued past this point into Rumuogba land, cutting across the Old Aba road as seen under the Miniokoro Bridge, to Mini Ewa and finally to Woji community proper. Its multiple community connectivity anchors the environmental relevance of it hydro-geomorphic status, as well as, its vulnerability to human interferences.

At the Woji area, the river channel widened as it crosses the railway bridge. It maintained this broad width, though at a small divergent angle, through to Slaughter Bridge (Trans-amadi area), then into the Amadi Creek behind the Port Harcourt Zoo and finally joined the Bonny River, a trajectory of the Atlantic Ocean.

\section{Geology and Relief}

The entire Rivers State region barely stands at a mean elevation of $14 \mathrm{~m}$ a.s.l. (Fig. 2). Hence it is dominated by low lying coastal plains of the Niger Delta sedimentary formation. The Woji River drainage basin is an integral component of the Niger Delta geologic formation which covers an area of 75000 $\mathrm{km}^{2}$, approximately $60 \%$ of the $800 \mathrm{~km}$ coastline of Nigeria (Oyegun, Adeyemo 1999). The catchment has a stratigraphy of an arcuate sedimentation of
Cretaceous and Palaeogene sediments of well over 70 mln years ago, reaching a minimum depth of about $12 \mathrm{~km}$. There has been a cyclic reoccurrence of form, processes and phenomena starting from the initial Pre-santonian sea transgression in the Niger Delta. The sedimentary mix of the region is composed of three major geologic depositions found to emanate from the oil and gas rich alluvium (marine deltaic deposits) recent of the Eocene Agbada and Akata formations, the Coastal plain sands of Benin formation including Orashi shales, and the Lignite series of Cretaceous - early Paleocene era associated with the Imo Formation. The sequence of these depositions is lithologically observed lying relatively vertical through the Niger Delta environment (Merki 1970).

The Woji River drainage basin within Port Harcourt displays a maximum altitude of about $5 \mathrm{~m}$ a.s.l., sloping in a NW-SE direction to a low reading of 2.3 m (Umeuduji, Aisuebeogun 1999). Generally, this gives the Woji River drainage basin topography a mild gentle slope varying on an average between 3 and $5^{\circ}$.

\section{Climate, Soil and Vegetation}

The Woji River catchment, a subset of the larger Port Harcourt metropolitan area, experiences two distinct weather regimes namely: the dry and rainy seasons. The dry weather period, usually called the Harmattan, is experienced for a shorter period ranging from the months of December to March, while the rainy season covers most part of the year. The region receives heavy and prolonged rainfalls during the rainy season leaving its atmospheric moisture level high almost throughout the year, with its heaviest precipitation occurring in September with an average of $367 \mathrm{~mm}$ of rain. The least precipitation, on the other hand, is experienced at January with an average rainfall of $20 \mathrm{~mm}$. Temperatures throughout the year in
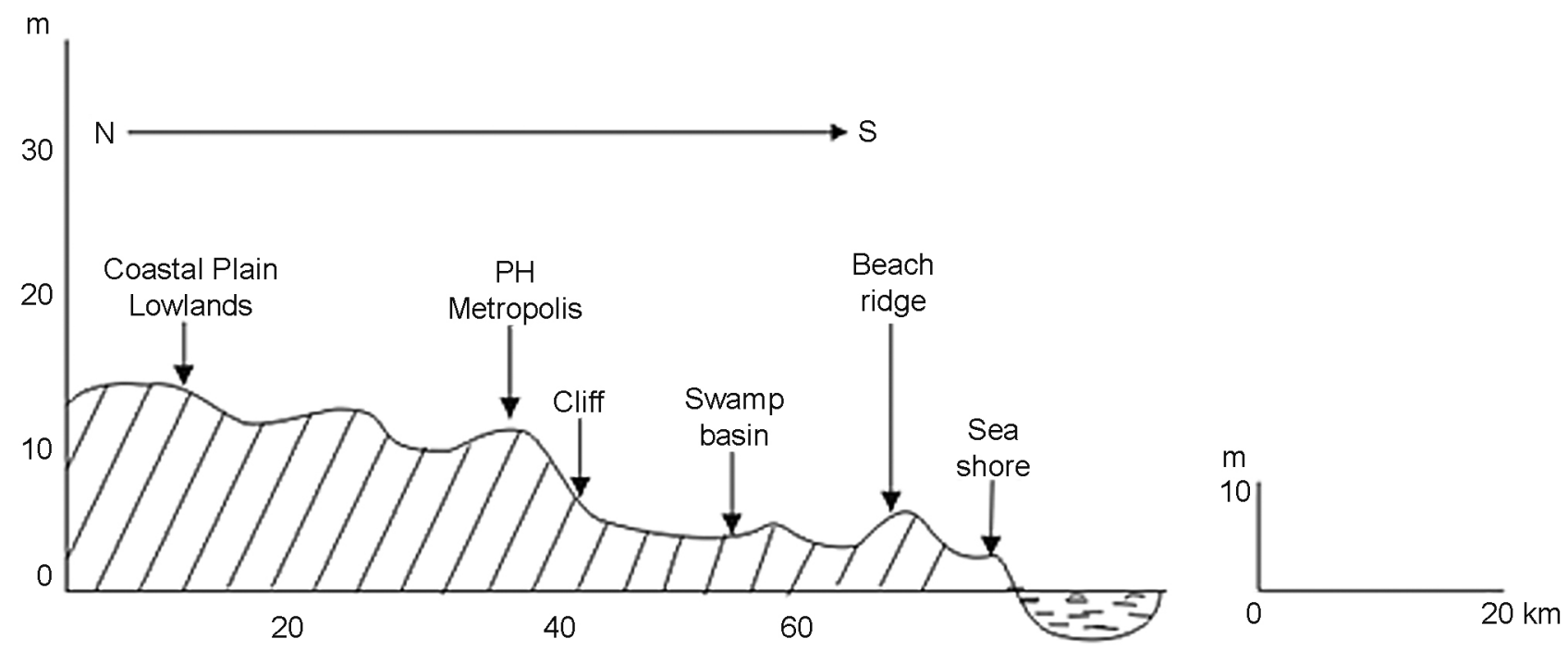

Fig. 2. Relief profile of Rivers State (Umeuduji, Aisuebeogun 1999) 
the Woji River drainage basin part of Port Harcourt city are relatively constant, showing little variation throughout the course of the year. Mean temperatures are typically between $25-28^{\circ} \mathrm{C}$ within the city, while the humidity range for the Woji region stands at $26.8 \%$ throughout the whole year (NMA 2008).

The soil within the Woji River catchment is of the older sediments derived from the coastal plain sands. The soil profile shows coarse sandy clay, deep, very porous and brown coloured. It is low in fertility, mainly composed of quartz and kaolinite minerals. The soil here experience intense leaching from heavy annual rainfall, the reason for showing pale tone of its colour. Soil type ranges from sandy to sandy loam superficially (Oyegun, Adeyemo 1999). With the speeding up of urbanization in Port Harcourt since the early $60 \mathrm{~s}$, most of its rainforest vegetation are gone; consumed in land use change hence, leaving the region barely with mosaic farm land bushes (Arokoyu, Weli 2008).

\section{Materials and Method}

Both primary and secondary data were acquired for the purpose of achieving the objective of this work. Here, a temporal experimental design was adopted, including the use of mathematical interpolations, in analysing the various effects of urbanization treatment on the drainage morphology of Woji River basin. A base year of 1986 was gestated in this research following after the history of active urbanization within Port Harcourt and subject to the availability of past satellite imageries of the focused region. A strategic comparison of the base year 1986 and year 2016 was made yielding a sampling gap of 30 years interval. A gap range of a reasonable time to reflect any urban induced change on the catchment. Satellite imageries of the Woji River drainage basin covering 1986 and 2016, were acquired and processed within a GIS medium. The digital elevation models (DEM) of these sampling years were developed and analysed using an ArcGIS 10.2 computer programme.

\section{River Profile Data}

The time trend data were generated in two groups; those extracted from 1986 base year DEM and those from the study year 2016 field measurements. The GARMIN 76 handheld GPS receiver was used in measuring coordinates and thirty (30) sampling points were strategically mapped out at the various river reaches (using an $n$th term interval of $157 \mathrm{~m}$ in-between the reaches of the $4.7 \mathrm{~km}$ long river). River cross sectional measurements were carried out at these spots.
Cross section linear measurements of the channel bankfull width and depth were made in 2016 using the calibrated tape and ranging pole tools. The river flow velocity readings were made using an impeller meter device. At each reach, the meter reading was taken at five (5) different points along a cross-section at a depth range of 6 to 8 inches. The mean figure thereafter was taken as the flow velocity. A bankfull width and depth measure was essential as it signifies the river flow at its hydraulic efficiency. The cross section area $\mathrm{A}=\mathrm{W} \times \mathrm{D}$, and bankfull discharge $\mathrm{Q}=\mathrm{W} \times \mathrm{D} \times \mathrm{V}$ were afterwards derived from the primary field measurements using the Volume-Area method (Goudie 1991), where A - cross section area, W - channel width, D - mean depth of channel, V mean flow velocity and $\mathrm{Q}$ - bankfull discharge.

The ratio of elevation between the River highest point (source) and its lowest point at the mouth region gave the Rise $-4.82 \mathrm{~m}$, and the Run is 4,43 $\mathrm{m}$, therefore, yielding a $0.00109 \mathrm{~m}$ equivalent slope. This represents a gentle sloping region and a strong influence on the hydrology of the catchment.

\section{Channel Width, Discharge and Stream Power}

The 1986 river channel landcover was ascertained through the developed Woji River drainage basin DEM from a high resolution imagery capture of that year. The mean readings for hydrologic variables of width, velocity-depth quotient and discharge $\mathrm{Q}$ of the Woji River were interpolated mathematically using agreeing hydrologic equations.

The past channel width of the Woji River was extrapolated mathematically from its 2016 measurements. This was permissible mathematically due to similarities in the influencing hydrologic factors of rainfall, temperature, geology and the basin area following the methods of Herschy (1995). The extrapolation equation was modified to suit the both the available and the required variables of this work for the years 2016 and 1986; thus:

$$
\mathrm{Q}_{2}=\mathrm{Q}_{1} \times \frac{A 2}{A 1} \times \frac{W 2}{W 1}
$$

where:

- $\mathrm{A}_{1-2}$ - the basin area,

- $\mathrm{Q}_{1-2},-$ mean water discharge, and

- $\mathrm{W}_{1-2}$ - mean channel width.

Since the basin area was found unchanged in both years, therefore, the driving variable for the expected change in morphometry becomes the mean channel width adjustment. Hence modifying the equation to suit:

$$
\mathrm{Q}_{2}=\mathrm{Q}_{1} \times \frac{W 2}{W 1}
$$


In estimating the wetted perimeter $(\mathrm{P})$ of the Woji River for 2016 assessment year, the adjusted Manning Equation for discharge was used (Herschy 1995), that is

$$
\mathrm{Q}=\mathrm{AR}^{2 / 3} \mathrm{Sl}^{/ 2} / n
$$

where:

- Q- discharge,

- A - channel area,

- $\mathrm{R}$ - the hydraulic radius,

- S - channel slope and

- $n$ - Manning factor, which holds an acceptable range of $0.02-0.025$ for a straight channel with a sandy bed floor sediments (Herschy 1995); the value 0.025 was adopted for $n$ in this calculation.

With the mean channel width measurement of the river in $2016\left(\mathrm{~W}_{1}\right)$ at $13.87 \mathrm{~m}$ (Table 1), there- fore, its 1986 counterpart $\left(\mathrm{W}_{2}\right)$ is calculated thus: Inferring from figure $5, \mathrm{~W}_{1}$ occupied $2.63 \%$ of the entire Woji River Basin in the year 2016, while $\mathrm{W}_{2}$ was equivalent to $5.26 \%$ in the 1986 year.

Therefore, $2.63 \%=13.87 \mathrm{~m}$ and $5.26 \%=\mathrm{W}_{2}$. Equating the averages:

$$
\frac{2.63}{5.26}=\frac{13.87}{W 2}
$$

Hence, $\mathrm{W}_{2}=13.87 \times 5.26 / 2.63=27.74 \mathrm{~m}$.

Extrapolating the river's mean cross-sectional discharge $\left(\mathrm{Q}_{2}\right)$ after Herschy (1995) displayed in equation 1 and 2 .

$\mathrm{Q}_{2}=10.46 \times \frac{75.74}{37.87}$, which is equal to $20.92 \mathrm{~m}^{3} \mathrm{~s}^{-1}$.

The river stream power and specific stream power calculations were done importing formulae 4 and 5:

\begin{tabular}{|c|c|c|c|c|c|c|}
\hline \multirow{2}{*}{ Sampling } & Width & Depth & W/D Ratio & Velocity & Discharge & Morphology \\
\hline & \multicolumn{2}{|c|}{$[\mathrm{m}]$} & {$[-]$} & {$\left[\mathrm{ms}^{-1}\right]$} & $\mathrm{m}^{3} \mathrm{~s}^{-1}$ & $\mathrm{~m}^{2}$ \\
\hline 1 & 1.68 & 0.79 & 2.00 & 0.28 & 0.37 & 1.33 \\
\hline 2 & 1.60 & 1.02 & 1.00 & 0.30 & 0.49 & 1.63 \\
\hline 3 & 2.46 & 1.21 & 2.00 & 0.30 & 0.89 & 2.98 \\
\hline 4 & 4.86 & 1.34 & 3.00 & 0.31 & 2.02 & 6.51 \\
\hline 5 & 8.78 & 1.66 & 5.00 & 0.34 & 4.96 & 14.57 \\
\hline 6 & 10.92 & 1.65 & 6.00 & 0.33 & 5.95 & 18.02 \\
\hline 7 & 6.18 & 1.45 & 4.00 & 0.35 & 3.14 & 8.96 \\
\hline 8 & 16.76 & 1.42 & 11.00 & 0.41 & 9.76 & 23.80 \\
\hline 9 & 9.69 & 1.35 & 7.00 & 0.36 & 4.71 & 13.08 \\
\hline 10 & 3.50 & 1.64 & 2.00 & 0.32 & 1.84 & 5.74 \\
\hline 11 & 7.47 & 1.43 & 5.00 & 0.34 & 3.63 & 10.68 \\
\hline 12 & 11.00 & 1.20 & 9.00 & 0.39 & 5.15 & 13.20 \\
\hline 13 & 6.78 & 1.51 & 4.00 & 0.38 & 3.89 & 10.24 \\
\hline 14 & 12.90 & 1.63 & 7.00 & 0.36 & 7.57 & 21.03 \\
\hline 15 & 21.30 & 2.00 & 10.00 & 0.38 & 16.19 & 42.60 \\
\hline 16 & 18.83 & 1.64 & 11.00 & 0.35 & 10.81 & 30.88 \\
\hline 17 & 8.86 & 1.42 & 6.00 & 0.33 & 4.15 & 12.58 \\
\hline 18 & 14.54 & 2.10 & 6.00 & 0.37 & 11.30 & 30.53 \\
\hline 19 & 10.03 & 2.00 & 5.00 & 0.34 & 6.82 & 20.06 \\
\hline 20 & 12.16 & 1.65 & 7.00 & 0.39 & 7.82 & 20.06 \\
\hline 21 & 13.19 & 1.65 & 7.00 & 0.38 & 8.27 & 21.76 \\
\hline 22 & 16.58 & 1.74 & 9.00 & 0.34 & 9.81 & 28.85 \\
\hline 23 & 5.79 & 2.00 & 2.00 & 0.35 & 4.05 & 11.58 \\
\hline 24 & 5.60 & 1.88 & 2.00 & 0.34 & 3.58 & 10.53 \\
\hline 25 & 12.80 & 2.24 & 5.00 & 0.36 & 10.32 & 28.67 \\
\hline 26 & 10.81 & 2.19 & 4.00 & 0.33 & 7.81 & 23.67 \\
\hline 27 & 22.40 & 2.42 & 9.00 & 0.37 & 20.06 & 54.21 \\
\hline 28 & 43.97 & 2.73 & 16.00 & 0.39 & 46.81 & 120.04 \\
\hline 29 & 44.97 & 2.85 & 15.00 & 0.38 & 48.70 & 128.16 \\
\hline 30 & 49.82 & 2.40 & 20.00 & 0.36 & 43.04 & 119.57 \\
\hline Total & 416.23 & 52.21 & 202.00 & 10.53 & 313.91 & 855.52 \\
\hline Mean & 13.87 & 1.74 & 6.73 & 0.35 & 10.46 & 28.52 \\
\hline
\end{tabular}

Table 1. Woji River channel morphometry in 2016 


$$
\begin{gathered}
\Omega=\rho g Q s \\
P=\rho g Q s / w
\end{gathered}
$$

(4),

(5),

where:

- $\rho$ - water density $\left(1000 \mathrm{kgm}^{-3}\right)$,

- g-gravitational acceleration $\left(9.8 \mathrm{~ms}^{-1}\right)$,

- Q- water discharge,

- S - channel slope, and

- W - channel width.

\section{Urbanization Degree Estimation}

First a base year of 1986 was established through acquiring satellite imagery. Enhanced Thematic Mapper (ETM) image covering the study area 1986 and Enhanced Thematic Mapper plus (EMT+) of 2016 were used for land use change detection and analysis (Figs 3, 4).

The level of urbanization within Woji River drainage basin was computed as the ratio of total landuses associated with urban activities to the basin area. The rate of urbanization growth was deduced from the net of urbanization index of the two year under scrutiny, i.e., 1986 and 2016. Such urban indices / parameters were inferred from air photographs hence obviating unnecessary tedious field survey according to Goudie (1991). Analysis of Landsat ETM 7 imagery of the region of study manipulated in an ArcGIS 10.2 medium was employed to classify various urban land uses. Following after Lewin and Manton (1975), colour imagery of 1:5000 scale provides clear tonal variation identifying vegetation patterns and permits high estimation to $\pm 0.10 \mathrm{~m}$. Hence DEM for land uses were developed, defined and measured accord-

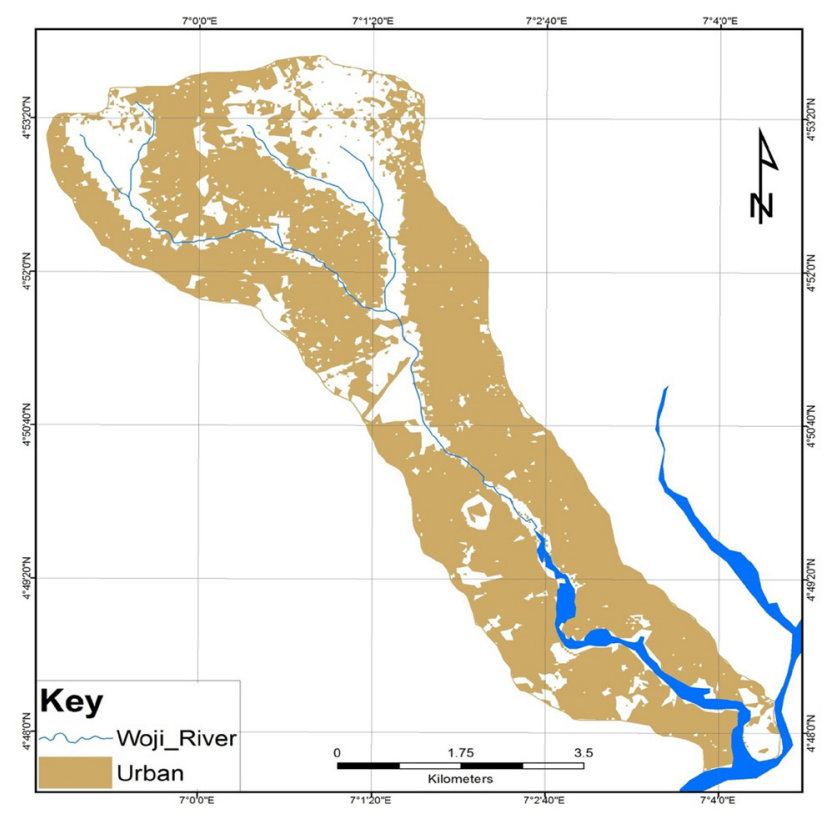

Fig. 3. Classified Satellite Image of the Woji River Basin showing urban areas in 1986

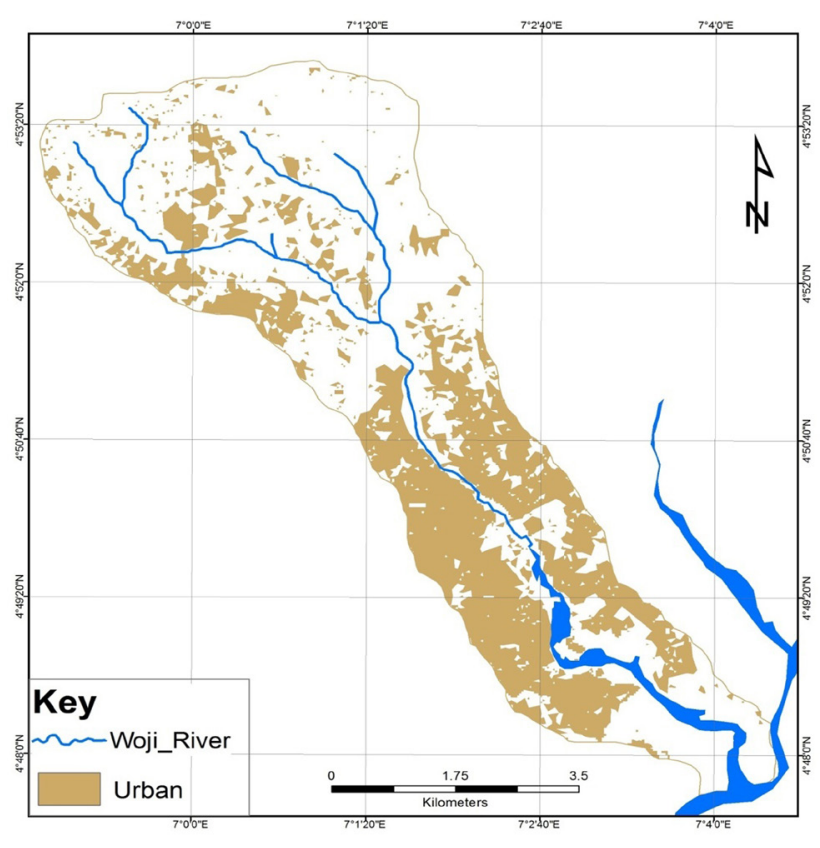

Fig. 4. Classified Satellite Image of the Woji River Basin showing urban areas in 2016

ingly. The procedure followed include; composite banding or layer stack procedure using ERDAS 2014, pixel training session in ERDAS, maximum likelihood classification and surface aspect.

\section{Results and Discussion}

\section{Characteristics of the Basin}

The Woji River currently shows high signs of channel siltation consequent its urbanization; most of these sediments trapped within its reservoirs and banks. The prolonged high sediment influx taking place over the years the catchment is undergoing urbanization (since the 1960s) gave rise to such channel siltation, which in turn affects the geomorphic equilibrium order of the River channel. In addition to this, the river gully is most times dredged in response to one flood event or the other - a situation that has permanently destroyed the historic sensors of the river flow and culminating in haphazard hydrologic exchanges (Fig. 5).

The trend line showed strong irregularity in the river bank grading, a future divulging uninterrupted fluvial activity. This altered river channel forms now control the flow of water downstream, which advertently influence the magnitude of flooding events being experienced throughout the floodplain (Torresan 2015).

Apart from the region's geologic factors, the overall peneplain topography of the Woji River catchment is also attributed to the high level of urban 




Fig. 5. Width-depth ratio trend-line plotting of the Woji River

land uses, predominated with residential quarters and constructed motor ways. Most of its undulated topography have either been filled or lowered to suit the housing and developmental projects, leaving only few micro relief forms of anthropogenic origin to perform, oftentimes, contradicting tasks of the natural divides. A large percentage of these land surfaces are highly impervious due to cementing works from paved yards, buildings, roads, gutters and culverts constructions, thereby, causing the river channels to be overlaid with runoffs during storms. Bulk of the catchment precipitation is drained through the rigour of networks of open river channel, overland flows and artificial drainages, as compared to the volume that percolates.

\section{Channel Morphometric Analysis}

In 2016, the catchment's mean cross-sectional discharge $\left(\mathrm{Q}_{1}\right)$ was $10.46 \mathrm{~m}^{3} \mathrm{~s}^{-1}$, while in 1986 it $\left(\mathrm{Q}_{2}\right)$ originally was $20.92 \mathrm{~m}^{3} \mathrm{~s}^{-1}$ as extrapolated (section 4.3.1). Likewise the mean channel width had shrunk by 2016 when compared to its 1986 extrapolated figure of $27.74 \mathrm{~m}$. Summary of the mean channel morphometric variables of the Woji River for 1986 and 2016 are reviewed in Table 2.

The comparative table remark first shows that the river channel landcover shrank by $50 \%$ from its original landcover area in 1986. Other accompanying morphometric changes mathematically followed suit in this reduction of channel landcover. Channel

Table 2. Woji River channel (mean) morphometry extracts

\begin{tabular}{clcrcc}
\hline S/N & Parameter (mean) & Unit & \multicolumn{1}{c}{1986} & \multicolumn{1}{c}{2016} & Remarks \\
\hline 1 & Channel mean width & {$[\mathrm{m}]$} & 27.74 & 13.87 & Reduced Mean Width \\
2 & Channel $(\mathrm{dv})$ & {$\left[\mathrm{m}^{2} \mathrm{~s}^{-1}\right]$} & 0.87 & 0.61 & (dv) reduced \\
3 & Mean water discharge $(\mathrm{Q})$ & {$\left[\mathrm{m}^{3} \mathrm{~s}^{-1}\right]$} & 20.92 & 10.46 & Less Discharge \\
4 & River channel cover & {$[\%]$} & 5.26 & 2.63 & Less landcover \\
5 & Stream power & {$[\mathrm{W}]$} & 223.47 & 111.73 & Less eroding capacity \\
6 & Specific stream power & {$\left[\mathrm{Wm}^{-1}\right]$} & 8.06 & 8.06 & Less force to move sediments \\
\hline
\end{tabular}


mean width reduced by $50 \%$ (from $27.74 \mathrm{~m}$ it was in the year 1986 to $13.87 \mathrm{~m}$ in 2016), the mean channel full capacity discharge also dropped by $50 \%$ (from its $20.92 \mathrm{~m}^{3} \mathrm{~s}^{-1}$ in 1986 to a mean figure of $10.46 \mathrm{~m}^{3} \mathrm{~s}^{-1}$ in 2016), and ultimately reducing the stream power from 223.47 Watt in 1986 to a staggering low channel energy of 111.73 Watt (Table 2).

The Woji River channel is faced with three unfavourable geomorphic conditions induced by high level of urbanization processes. High Horton's Overland Flows caused by such activities as erection of buildings, roads, bridges and culverts constructions and increasing agricultural land uses. Secondly, mass devegetation - a consequence of the first condition and lastly, the availability of loose surface sediments which ends up being washed into the river channel and floodplain at flood experiences.

This sequence of effect within the Woji River catchment followed after Oyegun (1997) finding, that high siltation of urban river channels mostly occurs at the early part of the urbanization journey within a river catchment due to fast level of ongoing construction activities. The loose clastic particles became available out of vegetation loss and topography alterations by earth moving machines. Only little marshy vegetation are left to trail along the narrowed floodplain of the Woji River and cultivated edible/cash crops on land

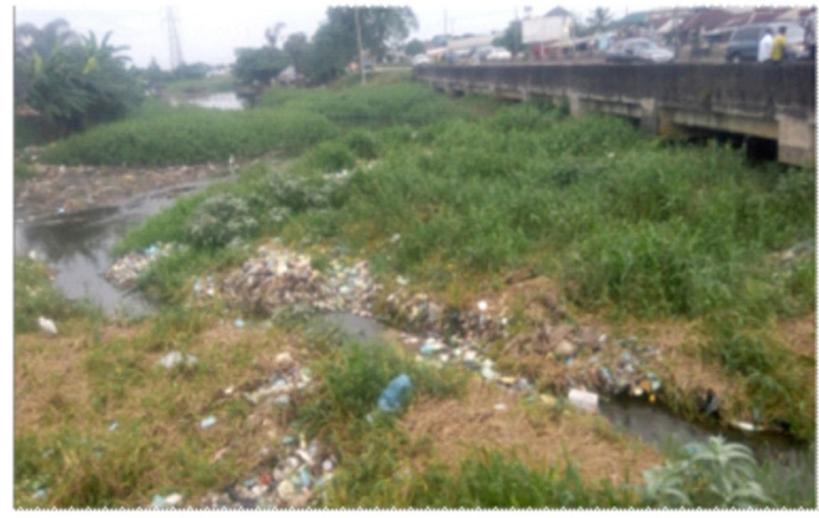

(a) Meandering flow amid channel blockages upstream



(c) Sand bag formation along cocaine estate axis plots yet to be built, with surface imperviousness increased at the same time leading to high volume of the Horton Overland Flows. The consequently deposited clastic sediment sizes are heavy compared to the available energy within the stream for its transportation, causing blockages within the slit-off phases of the Woji River channel and at its floodplains.

On-going land reclamation activities for house buildings at both Rukpokwu and Rumuodara wetlands which houses the Woji River source channels, construction of undersized culverts and bridges at various points of the river long profile have affected the hydrologic recharge processes of the stream. These obstructions produce damming effect since the river free flow is interrupted intermittently, with a resulting lowered hydraulic radius, unit stream power and gradual covering of the downstream channel as the river no longer have need to maintain its channel excess capacity (Zhu et al. 2017). Further consequence on the channel morphology is seen in the developing sinuosity of the river channel, the midstream siltation and formation of sandbags within the channel (Fig. 6).

The culvert construction at Eliozu axis altered the normal grading of the river slope giving rise to the steep path having a high discharge and ensuing a culvert-end undercut erosion as can be noted from the developed water fall (Fig. 6b). The entrained sed-

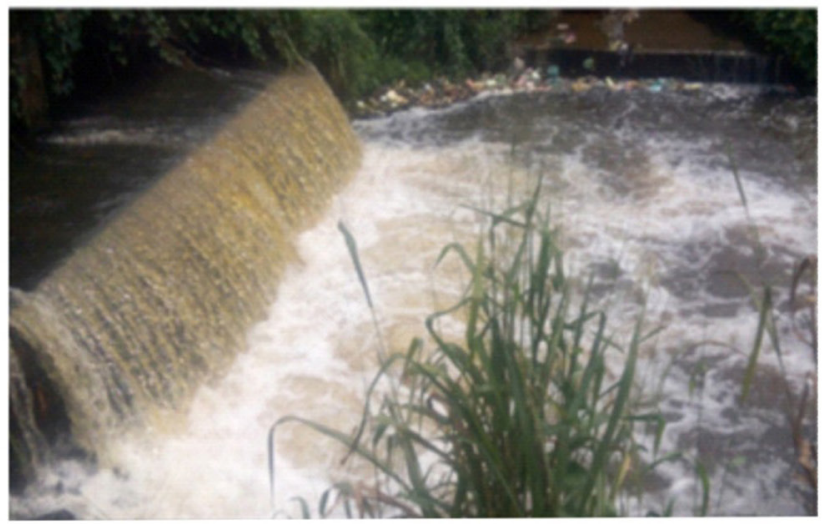

(b) Culvert ending creates a fall in the channel

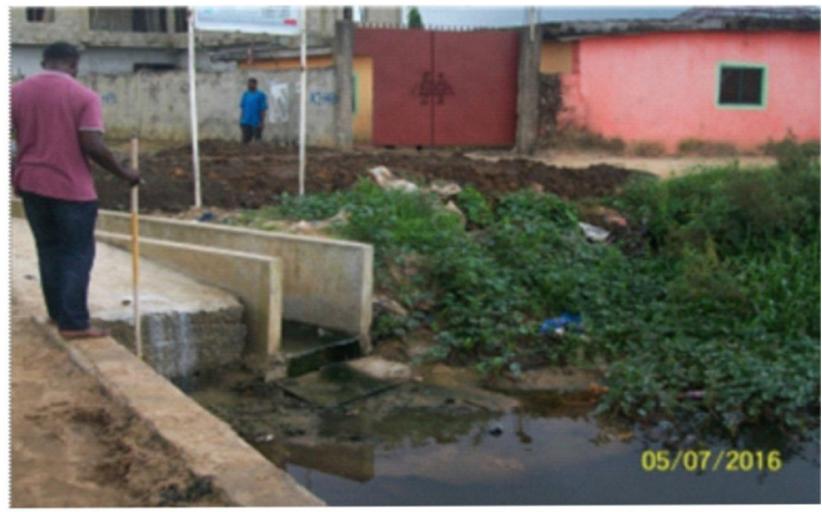

(d) Bank erosion threatening the urban structure

Fig. 6. Interruptions within the Woji River channel and consequent impacts 


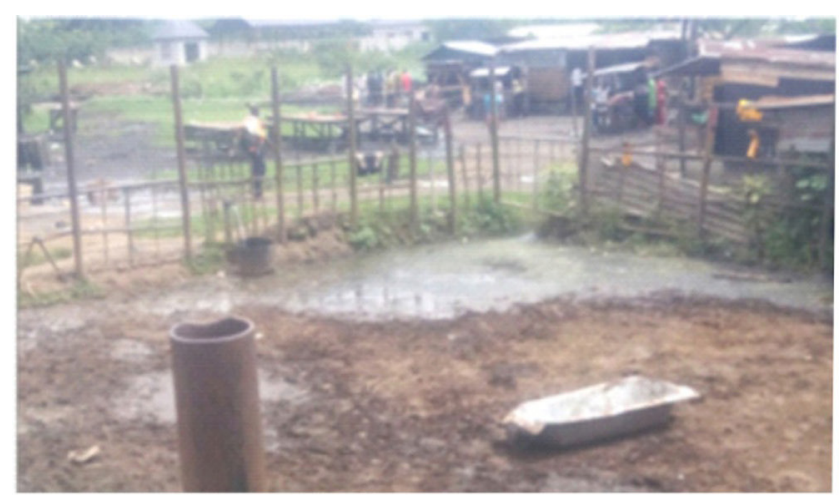

(a) Abattoir operated along the river floodplain

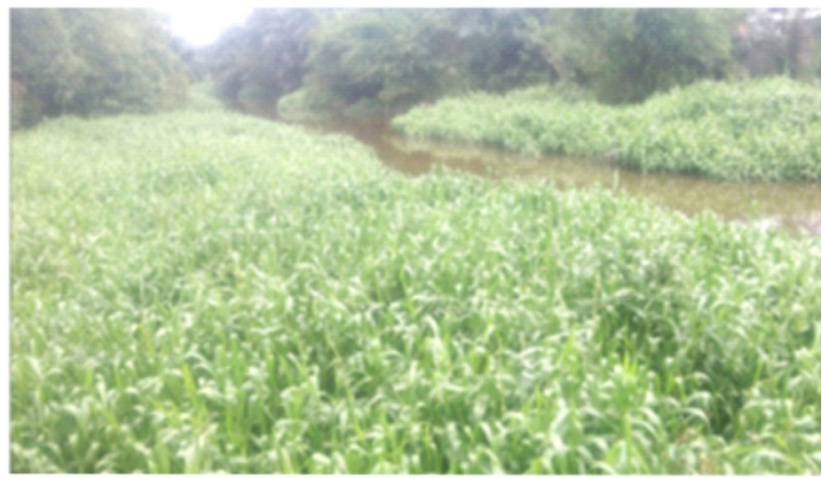

(b) Thick cover of water hyacinth downstream

Fig. 7. Water Hyacinth along the river channel and an Abattoir upstream

iments from the fall will soon deposit as the driving energy dissipates quickly forming the sand bags in a few meters down the river channel (Fig. 6c). Another obstructing scene at the Woji River channel is the high level of water hyacinth growth in the water way through the Eliozu region (Fig. 7). The discharge of animal remains/wastes generated from the abattoirs sited along the river floodplains into the river channel introduces high organic nutrients which has encouraged the hyacinth growth. These plants obstructs the river flow velocity and discharge, hence reducing the channel sediment transporting activities, while at the same time wedging floating urban garbage on the channel, amidst other hydrology implications.

Most worrisome amidst all other conditions surrounding the Woji River, as discovered, is the protracted dying state of its flow. From the thirty year gap analysis done, there has been a progressive reduction in the discharge of the river, while the catchment sediments supply accelerated from urban land use activities. Analysis showed that the specific stream power of the river dwindled over the years, despite the torrential rainfall under the present day global climate change scenario. Back in 1986, the river specific stream power was $8.06 \mathrm{Wm}^{-1}$ but showed no significant difference in 2016, a reflection of only a gradual loss of energy to do the required eroding and transporting work in maintaining an open active channel.

The retrogressive nature of the morphological variables within the Woji River drainage basin is clearly displayed in Table 3, as the mean negative impacts have been analysed down to their yearly implications. The channel constriction draws down alongside the mean river discharge and the accompanying mild reducing specific stream power. This help explains the progressive dying path of the river. Following Table 3, a predicted extinct period of the Woji River flow was calculated at about 27.26 years from now (i.e. about the year 2043), if nothing is done to save it from further deterioration as induced daily by urbanization processes (Table 4).

The stream fluvial discharge will first cease, while the open valley will over a speculated period of another 30 years gradually covered with upland transported sediments.

\section{Conclusion and Recommendation}

This study set out to evaluate a time-trend morphological impact on the Woji River channel due to ur-

Table 3. Mean yearly adjustments in the Woji River morphometry

\begin{tabular}{lcrrcc}
\hline \multicolumn{1}{c}{ Parameter } & Unit & 1986 & 2016 & Net Result $/ \mathrm{Yr}$ & Loss per yr \\
\hline Specific Stream power & {$\left[\mathrm{Wm}^{-1}\right]$} & 8.06 & 8.06 & nil & nil \\
Channel Width & {$[\mathrm{m}]$} & 27.74 & 13.87 & $13.87 \mathrm{~m} / 30 \mathrm{yrs}$ & 0.46 \\
Stream Discharge & {$\left[\mathrm{m}^{3} \mathrm{~s}^{-1}\right]$} & 20.92 & 10.46 & $10.46 \mathrm{~m}^{3} \mathrm{~s}^{-1} / 30 \mathrm{yrs}$ & 0.35 \\
\hline
\end{tabular}

Table 4. The Woji River hydro-morphological processes predictions

\begin{tabular}{lcccc}
\hline \multicolumn{1}{c}{ Parameter } & Unit & $\begin{array}{c}2016 \text { channel variable } \\
(\mathrm{A})\end{array}$ & $\begin{array}{c}\text { Rate of Loss per Year } \\
(\mathrm{B})\end{array}$ & $\begin{array}{c}\text { Extinct point of Variable } \\
(\mathrm{A} / \mathrm{B})\end{array}$ \\
\hline Specific Stream Power & {$\left[\mathrm{Wm}^{-1}\right]$} & 8.06 & nil & nil \\
Channel Width & {$[\mathrm{m}]$} & 13.87 & 0.46 & 30.15 years \\
Stream Discharge & {$\left[\mathrm{m}^{3} \mathrm{~s}^{-1}\right]$} & 8.54 & 0.35 & 24.4 years \\
Mean Extinct Point of the & & & & 27.26 years \\
Channel Morphometric Variables & & & & \\
\hline
\end{tabular}


banization of its catchment, using some mathematical computations. The catchment DEM was developed for the study years 1986 and 2016, from which measurements of the geomorphic variables were made. The river discharge for 2016 was calculated using the hydraulic formula $\mathrm{Q}=\mathrm{W} \cdot \mathrm{D} \cdot \mathrm{V}$, while that of the 1986 year was extrapolated mathematically in section four of this paper. The research outcome showed a 50\% reduction in the Woji River channel width between the two years under survey. The mean stream discharge as well, dropped by 50\% as examined in 2016 with an accompanying reduction in the stream power from 223.47 W (in 1986) to a staggering low channel energy of $111.73 \mathrm{~W}$. The resulting effects on the river were high channel siltation due to the river eroding inability, recharge headstream region obstructions in the phase of rapid urban land use change, and serious reduction in its hydrologic flow. Other channel blockages were found to have been caused by water hyacinth invasion along the river flow path and its floodplain, urban domestic waste dumps into the water channel, and constrictions by narrow culverts and bridges. The overall outcome was identified dying state of the Woji River, which its terminal stage was projected to come by the year 2056, if nothing was done to improve on its state in nature.

A correction and monitoring exercise should be carried out to save the Woji River from drying out. To achieve this, the need for restoration of the Rukpokwu and Rumuodara wetlands become necessary in the light of the hydrologic flow drop within the river. This will help to build back the head stream recharge capacity of the river. The work also recommends prohibition of abattoirs around the river floodplains, prohibition of refuse dumping in the water ways and manual removal of water hyacinths as bedform friendly approach in place of dredging as the stream is already suffering from several construction interference along its channel. Finally, gauge stations should be established at various reaches of the river to facilitate monitoring exercises and future management of the entire river catchment.

\section{References}

Adebayo W., Arohunsoro J.S., 2014. Environmental Effects of Urbanization of River Ajilosun Drainage Basin in Ado-Ekiti, Ekiti State, Nigeria. Journal of Natural Science Research 4(2): $113-124$.

Arokoyu S.B., Weli V.E., 2008. Urban Flood Prediction in a Sub-Humid Tropical city: Implications for urban land use planning in Port Harcourt, Nigeria. Tropical Focus 9(2). Pacificam Douala.

Boix-Fayos C., Barbera G.G., Lopez-Bermudez F., Castillo V.M., 2007. Effects of check dams, reforestation and land-use changes on river channel morphology: Case study of the Rogativa catchment (Murcia, Spain). Geomorphology 91(1-2): 103-123.

Booth D.B., 1991. Urbanization and the Natural Drainage System - Impacts, Solutions, and Prognoses. The NorthWest Environmental Journal 7(1): 93-118.

Chin A., 2006. Urban Transformation of River Landscapes in a global contex. Geomorphology 79(3-4): 460-487.

Goudie A. (ed.), 1991. Geomorphological Technics. Allen and Unwin. Herschy R.W., 1995. Streamflow Measurement. CRC Press.

Lewin J., Manton M.M.M., 1975. Welsh floodplain studies: The nature of floodplain geometry. Journal of Hydrology 25 (1-2): 37-50.

Merki P.J., 1970. Structural Geology of the Cenozoic Niger Delta. African Geology, University of Ibadan, Ibadan: 251-265.

NMA [Nigerian Meteorological Agency], 2008. Nigerian Climate Review.

NPopC [National Population Commission], 2010. Population Distribution by Sex, State, LGA and Senatorial Districts. Abuja, Nigeria.

Ofomata, G. E. (2009). Basi Geomorphology for Africa. Enugu Nigeria: Jamoe Publishers.

Oyegun C.U., 1997. The Human Environment: Its Form and Processes. Port Harcourt: Jeson Services Ltd.

Oyegun C.U., Adeyemo A., 1999. Port Harcourt Region. A Paragraphics, Port Harcourt.

Paul M.J., Meyer J.L., 2001. Streams In The Urban Landscape. Annual Review of Ecology Systems 32: 333-65.

Torresan L.Z., 2015. What We Do: River Studies. Washinton, USA: U.S. Department of the Interior / U.S. Geological Survey.

Umeuduji J.E., Aisuebeogun A., 1999. Relief and drainage in Port Harcourt Region. In: C.U.Oyegun, A.Adeyemo (eds), A Paragraphics, Port Harcourt.

UNDP [United Nations Development Programme], 2004. Reducing disaster risk: a challenge fordevelopment. United Nations Development Programme, New York: 1-161.

Weli V.E., Ideki O., 2014. The Effect of Urbanization on Channel Adjustment and Flood Vulnerability of Woji Basin, Rivers State, Nigeria. Journal of Natural Sciences Research 4(10): 86-93.

Zhu B., Li Y., Yue Y., Yang Y., 2017. Aggravation of North Channels' Shrinkage and South Channels' Development in the Yangtze Estuary under Dam Induced Runoff Discharge Flattening. Estuarine, Coastal and Shelf Science 187:178-192. 